\title{
Archival Research for the Yturri-Edmunds Annex (Camp Roosevelt Tourist Camp) San Antonio, Bexar County, Texas
}

I. Waynne Cox

Center for Archaeological Research

Follow this and additional works at: https://scholarworks.sfasu.edu/ita

Part of the American Material Culture Commons, Archaeological Anthropology Commons, Environmental Studies Commons, Other American Studies Commons, Other Arts and Humanities Commons, Other History of Art, Architecture, and Archaeology Commons, and the United States History Commons

Tell us how this article helped you.

This Article is brought to you for free and open access by the Center for Regional Heritage Research at SFA ScholarWorks. It has been accepted for inclusion in Index of Texas Archaeology: Open Access Gray Literature from the Lone Star State by an authorized editor of SFA ScholarWorks. For more information, please contact cdsscholarworks@sfasu.edu. 


\section{Archival Research for the Yturri-Edmunds Annex (Camp Roosevelt Tourist Camp)}

San Antonio, Bexar County, Texas

\section{Creative Commons License}

(c) (i) (8)

This work is licensed under a Creative Commons Attribution-NonCommercial 4.0 International License 


\section{ARCHIVAL RESEARCH FOR THE YTURRI-EDMUNDS ANNEX (CAMP ROOSEVELT TOURIST CAMP) SAN ANTONIO, BEXAR COUNTY, TEXAS}

I. WAYNNE COX

CENTER FOR ARCHAEOLOGICAL RESEARCH THE UNIVERSITY OF TEXAS AT SAN ANTONIO ARCHAEOLOGICAL SURVEY REPORT, NO. 229 

The following information is provided in accordance with the General Rules of Practice and Procedure, Chapter 41.11 (Investigative Reports), Texas Antiquities Committee:

1. Type of investigation: Archival Research;

2. Project name: Yturri-Edmunds Annex;

3. County: Bexar;

4. Principal investigators: Jack D. Eaton and Robert J. Hard;

5. Name and location of sponsoring agency: San Antonio Conservation Society, 107 King William Dr., San Antonio, Texas 78204;

6. Texas Antiquities Committee Permit No.: none;

7. Published by the Center for Archaeological Research, The University of Texas at San Antonio, San Antonio, Texas 78249-0658, 1994.

A list of publications offered by the Center for Archaeological Research can be obtained by sending $\$ 1.00$ to the Center for Archaeological Research, The University of Texas at San Antonio, 6900 N. Loop 1604 West, San Antonio, Texas 78249-0658. 



\begin{abstract}
The Center for Archaeological Research of The University of Texas at San Antonio contracted with the San Antonio Conservation Society to conduct an archival investigation of land to the north of the Yturri-Edmunds Mill property. This land, presently owned by the Society, is to be

The property under investigation was the site of the Camp Roosevelt Tourist Camp, one of San Antonio's first privately owned tourist facilities. The history of the Concepción acequia was also investigated to establish the location within the property limits.
\end{abstract} developed. 
TABLE OF CONTENTS

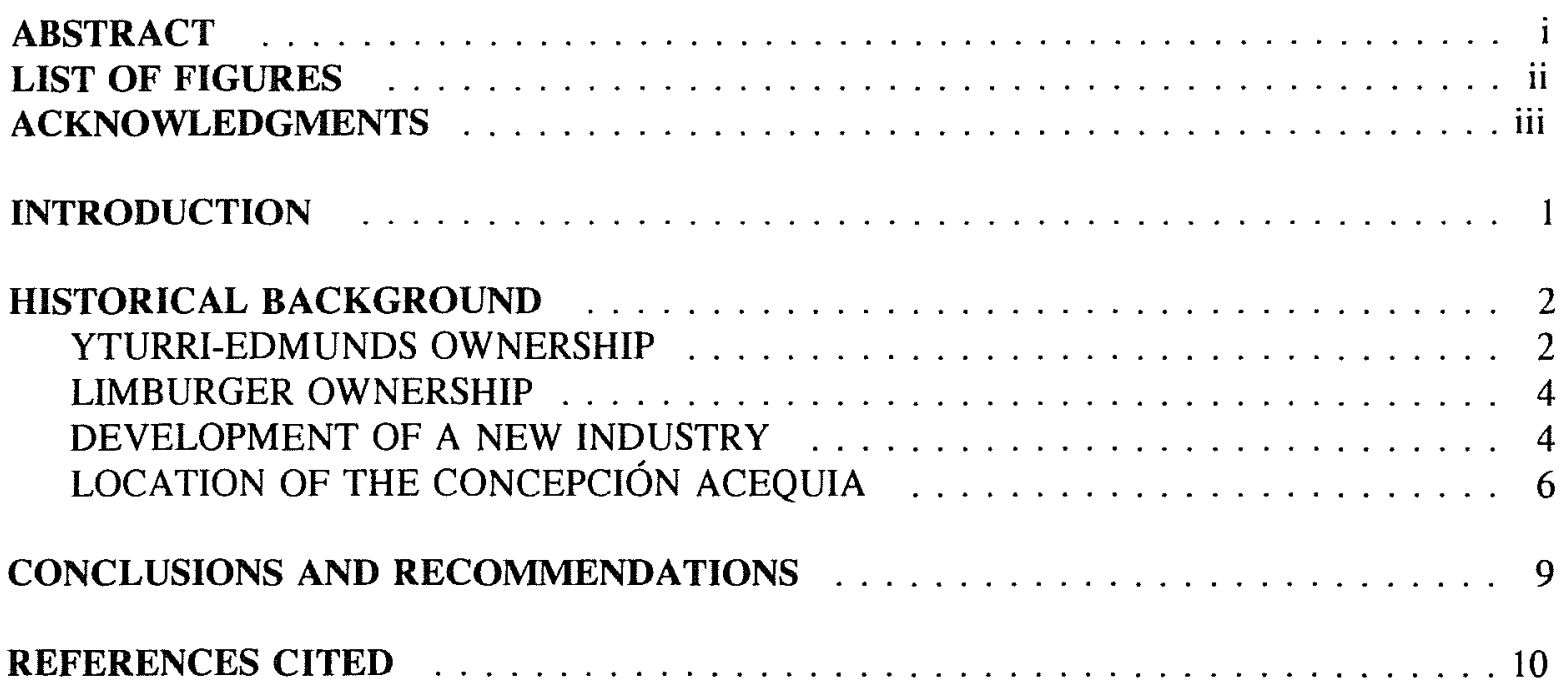

LIST OF FIGURES

1. Location of the Yturri-Edmunds property $\ldots \ldots \ldots \ldots \ldots \ldots \ldots \ldots$

2. Survey plats of the Yturri-Edmunds property $\ldots \ldots \ldots \ldots \ldots$ 


\section{ACKNOWLEDGMENTS}

We would like to take this opportunity to thank a few of the individuals who contributed to the research on this project. All staff members of the San Antonio Conservation Society were extremely helpful and went out of their way to make the information in their library and files accessible to our research. A special thank you to Bruce MacDougal for his understanding of the delay encountered with final publication.
Personnel of the Barker History Center in Austin, the San Antonio Public Library, the Library of the Daughters of the Republic of Texas, and the John Peace Library at UTSA facilitated the various avenues of research required by this project. John Leal, then Bexar County archivist, as always, opened his vast storehouse of information for our examination. And thanks go to Marcie Renner for serving as technical editor for the report. 



\section{INTRODUCTION}

In October 1990, the San Antonio Conservation Society contracted with the Center for Archaeological Research (CAR) of the University of Texas at San Antonio (UTSA) to conduct historical/archival research for the proposed Yturri-Edmunds North Annex property located on Mission Road just below Roosevelt Park in San Antonio. The property consists of .54 acres of land to be added to the YturriEdmunds Mill property acquired by the Society in 1961.

A search was conducted to determine the property history and uses over time. This search made use of the San Antonio Conservation Society files, the Bexar County Archives, Bexar County Deed Records, Bexar County Probate Records, the Barker History Center at Austin, UTSA Special Collections, CAR's files, and other sources.
The research revealed that the property was a portion of one of the first motor camps, or motor courts, in San Antonio. Dating from 1925 , the motor court was initially known as Camp Roosevelt. The research was conducted under the general direction of Jack D. Eaton, principal investigator and acting CAR director, and accomplished by I. Waynne Cox, research associate. Robert J. Hard, CAR director, served as principal investigator for the publication phase of the project. 


\section{HISTORICAL BACKGROUND}

\section{YTURRI-EDMUNDS OWNERSHIP}

The property in question was originally a very small portion of the upper labores or farm lands of Mission Nuestrá Señora de la Purísima Concepción de Acuña, generally referred to as Mission Concepción. The mission lands were secularized in August 1794 and portions were distributed among the 38 resident Indians of the mission (Habig 1968:141). The remaining lands were distributed to various individuals during the 1820 s by the newly formed Mexican government. In November 1823, Manuel Yturri Castillo petitioned the government for three suertes, or divisions, of land in the monte de palobanco (forest of hackberry trees); his request was granted the following month (Bexar County Deed Records [BCDR], Office of the County Clerk, Bexar County Courthouse, San Antonio, Volume A2:77). This was the land south of the mission bounded on its lower limit by the San Antonio River. In April 1824, Yturri requested, and was granted, three additional dulas of water (a measured amount of water usage) with the accompanying suertes of land. The three portions of land, 100 varas $[277.7 \mathrm{ft}]$ in width, were bounded on the north by the compuerte (sluice gate) of the Concepción acequia, on the east by San Juan Road, on the south by the lands of Don Erasmo Seguin, and on the west by Mission Road (Figure 1).

Manuel de Yturri Castillo was born in the Asturian Province of northern Spain and emigrated to Mexico in his youth. He became a clerk in the prestigious firm of Urtiaga Brothers and was appointed their San Antonio representative. On August 20, 1821, he married María Josefa Rodriguez, the daughter of Mariano Rodriguez and María de Jesus Carvajal, both of whom belonged to prominent San Antonio families (Chabot 1937:226; Rodriguez 1913:52-53).
In 1829 during his absence from the city, Manuel's wife appeared before the authorities to reestablish title to the grant for her husband (Cruse 1985:3). Upon the death of Manuel in March 1843, the property passed to his widow as executrix and guardian of their minor children, Manuel and María Josefa Vicenta Carmen (Bexar County Probate Records [BCPR], Office of the County District Court Clerk, Bexar County Courthouse, San Antonio, Volume B "Red":182-185). In 1847 María Josefa married County Judge Thomas Whitehead (Cruse 1985:4; Barnes 1910:239-240). She died in April 1849 and guardianship of her children passed to her father, Mariano Rodriguez; but in 1856, Whitehead brought suit and gained guardianship (Cruse 1985:4; District Court Records [DCR], Office of the County District Clerk, 1st series, case No. 1298). The son, Manuel, married in 1860 and his sister, Vicenta, was married the following year; upon marriage, each was placed in charge of his/her portions of the property. Vicenta received 100 acres of the mission lands and several town lots.

Vicenta met her future husband, Ernest B. Edmunds, in New Orleans where she was attending school. They were married August 5, 1861, at Mission Concepción by Father J. A. Faure (Bureau of Vital Statistics, Marriage Records [BVS-MR], Office of the County Clerk, Volume D2:294). By the time of Edmund's death on April 14, 1874, only about 10 acres of the inheritance remained in the hands of Vicenta and her children, Josephine, Edgar, and Ernestine (Cruse 1985:7). On April 2, 1904, Vicenta sold two tracts of the homestead, totaling 3.77 acres, to August Limburger (BCDR 226:613, 390:113). 


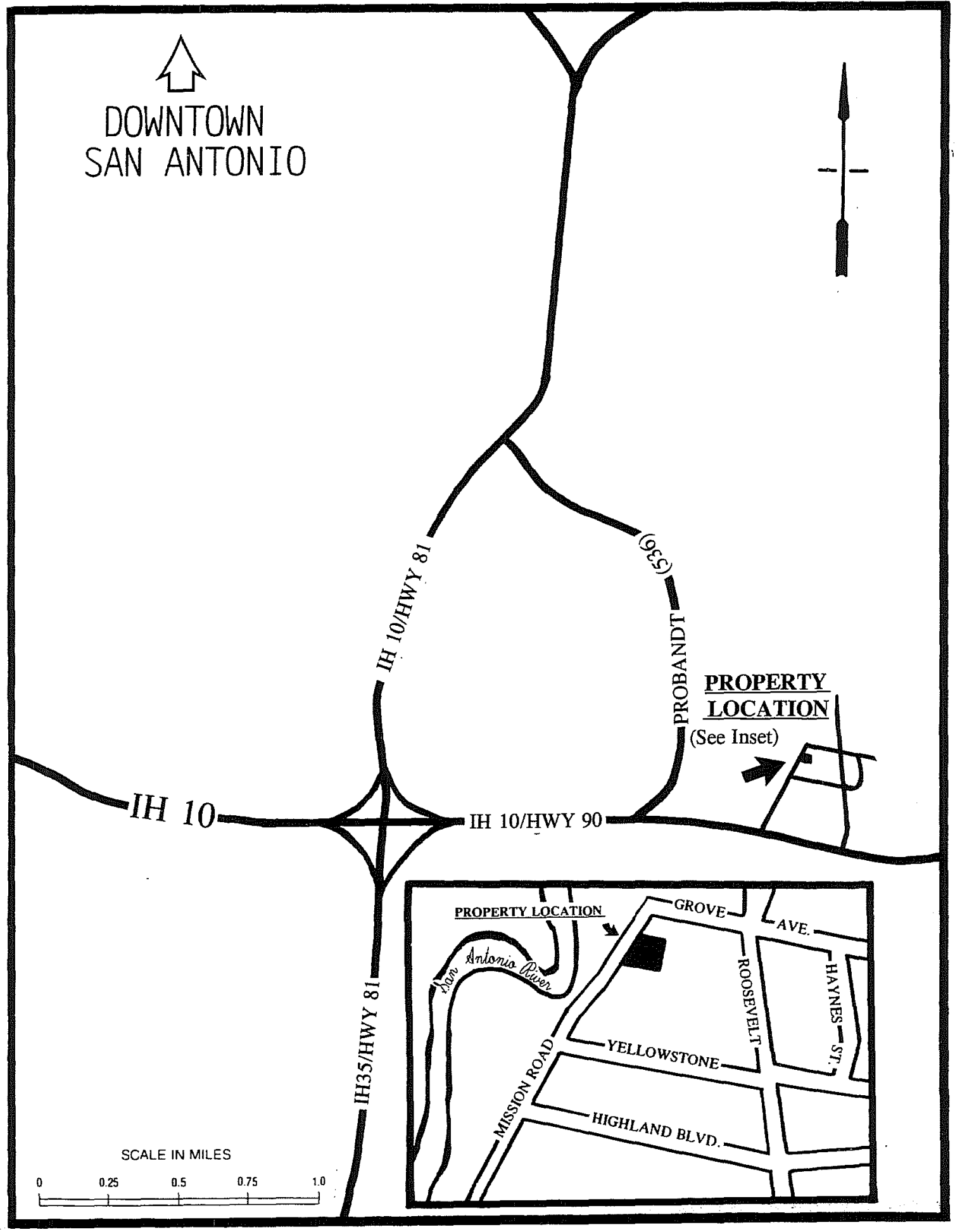

Figure 1. Location of the Yturri-Edmunds property. The area of the original Yturri grant and the location of the Yturri-Edmunds property under study are indicated. 


\section{LIMBURGER OWNERSHIP}

The first indication of the presence of the Limburger family in San Antonio appears in the 1881 city directory, when Henry Limburger is listed as a sausage stuffer for Henry F. Lohrberg (Morrison and Fourmy 1881). The same year Limberger purchased two lots on Austin Street from Samuel A. Maverick (BCDR 265:181). By 1885 Limburger had his own meat market on Austin Street and was employing his sons, Henry, Jr., Otto, and August as butchers (Morrison and Fourmy 1885, 1887). By 1889 he had added a saloon and, in 1895, established Limburger's Garden, a concert hall and saloon on what is now Broadway Avenue near the Witte Museum (Appler 1895). In 1901, August was the owner of the Metropolitan Bar on West Commerce Street and Henry, Jr. was manager of the Fulton Market on West Houston, employing Otto as a butcher (Appler 1901).

In February 1903, Otto married Viola Gillam. In October 1905, August married Mary Walsh, some five months after his purchase of the annex property from Vicenta Edmunds (BVS-MR $\mathrm{R}: 336, \mathrm{~T}: 422$ ). By 1907 Otto was residing on the property north of the mission at 201 Roosevelt Avenue, the street established at the north end of the property about 1903 (Appler $1901,1903,1907)$. In 1912 Otto established the office for his Southern Beef Company at the rear of the residence and, in 1921, purchased the property from his younger brother, August. However, August died before the note was paid and the indebtedness was cleared by the estate (Appler 1912; BCDR 646:598, 835:388). On the same day, July 16, 1925, Otto and Viola Limburger sold one acre of the property at the corner of Grove Avenue and Mission Road to Elmyra Wenninger (BCDR 835:388).

\section{THE DEVELOPMENT OF A NEW} INDUSTRY

The Wenninger purchase was made with a specific goal in mind, a commercial venture to serve the new tourist trade developing from the public fascination with the automobile. The automobile had been available to the public since the $1890 \mathrm{~s}$, but remained primarily a rich man's toy. Then individuals such as Ransom Eli Olds, Henry M. Leland, David Dunbar Buick, and Henry Ford began to produce motor cars within the reach of the average worker, and the public adopted the new machine (Hill 1967:21-34). In 1908 the Ford Model $T$ touring car sold for $\$ 850$, but the Hupmobile was priced at only $\$ 750$ and the Bush, "Everyman's Car," could be purchased for $\$ 490$. By 1908 Ford produced over a million Model Ts for $\$ 490$ each (Donovan 1965:103). A dealer in New York advertised his cars for $\$ 200$ down with 6 percent interest, the balance payable at $\$ 50$ monthly (Perry 1948:4). America had discovered the automobile and its potential.

In the period 1910-1920, several hundred thousand middle-class families toured the countryside, camping each night in a different spot along the road, sleeping in cars or tents, and cooking meals over smoky campfires. Auto campers called this squatter-anarchist stage "gypsying" (Belasco 1979:3). This habit of cooking on the road gained the appellate "tin can tourist" from local citizenry, and generally the owners of hotels and restaurants detested their appearance. Rather than viewing this title as an insult, travelers accepted it with pride, often decorating their hood ornaments with a tin can to identify their status. This lifestyle also freed the motorist from the expense and inconvenience of hotel lodging, but as their numbers increased, camping locations became more difficult to acquire and public facilities were missed by the families. 
By the early 1920s tourists generally began stopping in public campgrounds, normally located in municipal parks. In 1924 Texas had 174 such facilities (Belasco 1979:71). As their popularity grew, the demand upon the cities grew as well, and those cities hoping to gain the tourist trade began to increase their facilities. San Antonio had two parks suitable for camping, San Pedro and Brackenridge Parks. In April 1920 , a parcel of land was donated to the county by the widow of Henry Elmendorf, mayor from 1894-1897. This property consisted of ". . . the old exhausted gravel pit on Roosevelt Avenue . . . for park purposes only," and was transferred from the county to the city (BCDR 603:99). The following month, the tract was given the name Roosevelt Park (City Council Ordinance [CCO], Office of the City Clerk, City Hall, San Antonio, Volume MD 520.1:248). In February 1924 , the city authorized a contract for the drilling of an artisan well to supply water for a swimming pool (CCO MF 441:113).

The free municipal autocamp, while attracting tourists and their readily accepted money, also brought in what many considered an undesirable element. "In order to deal with these 'unmitigated nuisances,' many towns imposed fees, registration requirements, time limits, and police supervision at their camps" (Belasco 1979:106). The growing number of auto campers was becoming a problem as the automobile became a way of life for most families. In 1925 over $20,000,000$ motor vehicles were registered in the United States; $2,477,753$ more than in 1924, representing a 13.9 percent increase in one year alone (San Antonio Express [SAE] 3 January 1926). These factors created the opportunity for the growth of a new enterprise, the privately owned auto or tourist camp. Elmus and Elmyra Wenninger recognized this opportunity and acted to supply the need.

Elmus Wenninger (born July 6, 1886) married Elmyra Moore Anderson (born January 18, 1881 ) in San Antonio on October 22, 1921 (San Jose Cemetery, Wenninger plot, gravestones; BVS-MR 25:544). Elmus had a daughter,
Thelma, from a previous marriage and Elmyra also had a daughter, Mossie, from her first marriage to Anderson (BCPR No. 82148, 101253). At the time of their marriage, Wenninger was a salesman for the San Antonio Coffee Company (Worley 1924). On a family vacation to Colorado and Wyoming in 1923 , Wenninger was exposed to the concept of the privately owned tourist camps, and probably recognized the need for such facilities in San Antonio. In July 1925, the same month the Grove Avenue property was purchased, Wenninger applied for a permit for the construction of 12 one-room dwellings valued at $\$ 1,300$, and a few months later added four more units. This was the beginning of "Camp Roosevelt."

Wenninger's request for a permit was preceded four months earlier by a similar request by Edward Smith for the construction of 15 oneroom dwellings that became Camp Alamo at 111 Jones Road (Perry 1948:11). Which business opened first is not clear, for by the time of the next city directory in 1926, two other camps were listed: Mrs. Leta Thompson's Alta Tourist Camp, at 725 East Mulberry; and San Pedro Park Tourist Lodge, at 714 West Myrtle (Worley 1926). Camp Alamo does not appear in the listings until 1927; therefore, Camp Roosevelt may have been the first such camp to open for business in the city. By 1928 "everyone wanted a camp, thinking those who had camps were getting rich" (Keyton 1960:37). This certainly appears to have been the case in San Antonio because by 1929,19 tourist camps were in operation, over half located on the south side (Worley 1929).

The board and batten structure at 514 Grove Avenue (Unit F) appears to have served as both the Wenninger home and office, 518 Grove Avenue (Unit $\mathrm{H}$ ) appears to be the structure serving as a restaurant. Services provided included "water, fuel, toilets and bathing facilities, tables, benches, general store, lights, laundry facilities, tent platforms, cabins and community house" (Perry 1948:12). By 1929, 
518 Grove Avenue was a restaurant operated by James and Anna Peterson (Worley 1929).

On October 23, 1929, the stock market crash threw the national economy into crisis; however, at first the crash had little effect on Texas. Not until the financial collapse expanded to destroy the world market did the crash began to affect the state; European markets were no longer available and the price of cotton dropped to almost one-third its 1929 value. At that point Texas was drawn into the economic chaos (Fehrenbach 1968:650). Franklin D. Roosevelt's New Deal offered hope to many. During the famous "hundred days" (March-July 1933), Roosevelt was able to pass 13 vital measures, one of which was the Federal Relief Emergency Act (FERA), authorizing an appropriation of $\$ 500$ million for unemployment relief (Yass 1970:93-94). Governor Miriam Amanda Ferguson, using federal funds supplied by FERA, created the Texas Relief Commission (Branda 1976:Volume 3, 1130). Camp Roosevelt, now managed by Louis W. Brown, became the San Antonio division of the Texas Transient Bureau and the restaurant became the Relief Community House. Wenninger, although still the owner, was supplementing the family income with additional employment as a salesman (Worley 1934).

By 1936 Camp Roosevelt, again under the management of Wenninger, was back in operation as a tourist camp; the following year the restaurant was being operated by Mrs. Lillian A. Halton (Worley 1936, 1939). By 1946 the Wenningers were residing at 514 Grove, but it was no longer listed as a tourist camp and Elmus was employed as a real estate agent (Worley 1946, 1948, 1951). On July 25, 1953 , Elmus Wenninger died at age 67 in a local hospital $(S A E, 27$ July 1953). In his will (dated February 6, 1952) he left "the sum of $\$ 2000$ to my stepdaughter Mrs. Mossie Martin (nee Anderson) . . . and . . . to my dear wife, Elmyra Wenninger, all of the real estate of which I may die possessed" (BCPR, No. 82148). Elmyra reopened and managed the property, now known as Camp Roosevelt Cottages, until her death on December 19, 1958 (Worley 1957, Polk 1958). Her will bestowed all of her property to ". . . my beloved daughter, Mossie Martin" (BCPR No. 101253). The daughter renamed the property the Grove Avenue Cabins Tourist Courts, and continued to operate them as Mossie Anderson until 1967, when the courts were listed as managed by Jay and Mossie Dawson (Polk 1963, 1967). By 1973, the courts were again owned and managed by Mossie Anderson and remained so until 1977, when they were listed as vacant. The address was dropped in 1982 (Polk 1973, 1974, 1975, $1977,1979,1982$ ), thus ending over 50 years of service to a major component of the tourist industry.

\section{LOCATION OF THE CONCEPCIÓN ACEQUIA}

The Concepción or Pajalache acequia (Spanish water ditch) has been reputed to be "the oldest of all the acequias" (Corner 1890:43). While the Alamo acequia likely deserves that distinction, the Concepción acequia is certainly one of the oldest in the San Antonio valley. It was probably established to serve the first site of Mission San José y San Miguel de Aguayo prior to its relocation, in approximately 1729 , to its present site (Habig 1968:88). The acequia originated at a dam above the major ford of the San Antonio River near Presa Street. It basically followed what is now South St. Mary's Street until it reached the compuerte (sluice gate) at Groveton Street. It then divided into two branches, one following the road to the road to Mission Concepción; the other flowing to the east down the middle of the farm land along the road to Mission San Juan, now roughly the location of Roosevelt Avenue.

Flooding on the river prompted public pressure to remove the dam as an obstruction to river flow (Corner 1890:43). City Council approved its removal in March 1870 (City Council 
Minutes [CCM], Office of the City Clerk, March 23, 1870). In order to continue providing a flow of water to the field south of the city, a portion of the water from the Alamo acequia was diverted into the Concepción ditch (Corner 1890:43). At that time the branch flowing beside Mission Road was likely discontinued and the reduced flow directed toward the eastern branch where the fields were still in active use.

The branch along Mission Road passed through the Yturri grant, on the western margin of the property under examination. This ditch had probably fallen into disuse prior to 1863 , with the water for the fields being furnished by the eastern branch discharging into the river. In the survey of 1863 (Figure 2a) the eastern branch can be seen labeled "old ditch" across lots one and three, the location of the property under investigation and the Yturri-Edmunds homestead, respectively (County Survey Books [CSB], Office of County Clerk, Bexar Archives, Bexar County Courthouse, A-9:64). A lateral (Ditch A) divides the property from lot 5 , at the time belonging to Asa Mitchell, flowing from a central lateral of the acequia (Ditch B). A dashed line indicates an additional "old ditch" which may have been a long abandoned branch originating from the Mission Road branch, crossing lots one and three. However, an additional survey (Figure $2 b$ ) clearly shows this ditch was a diversion of Ditch $A$ and did not enter the Yturri property (CSB A-9:109). According to a plat produced by Louis Polk in 1923, Ditch A would have formed the southern edge of New City Block 6306 of the E. V. Edmunds subdivision below Yellowstone Street (BCDR 642:124-plat). Polk's plat also indicates a dashed line across the homestead division. This line has been regarded as the vestige of an acequia; however, the symbol shown is reserved to indicate fence lines unless otherwise noted. Therefore, the evidence at present indicates that any traces of the acequia on the Camp Roosevelt property should lie buried below fill near the western edge of the property. 


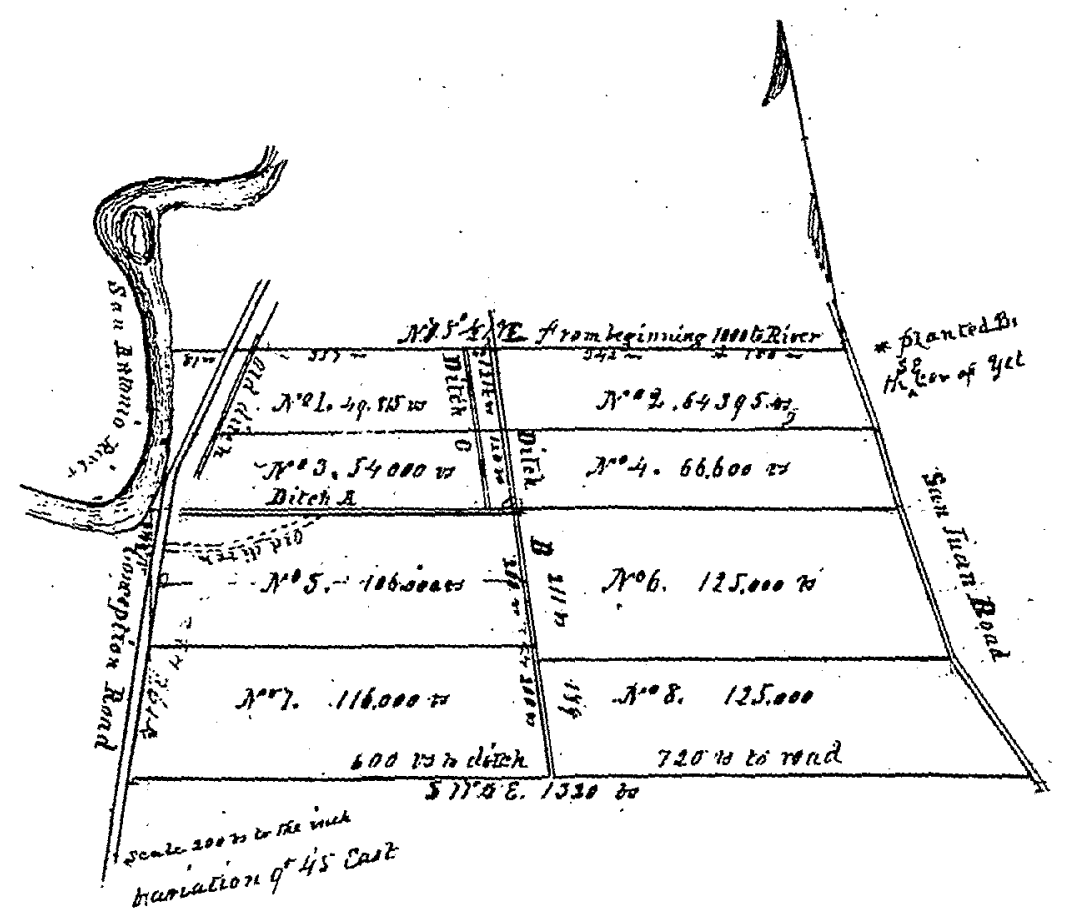

a

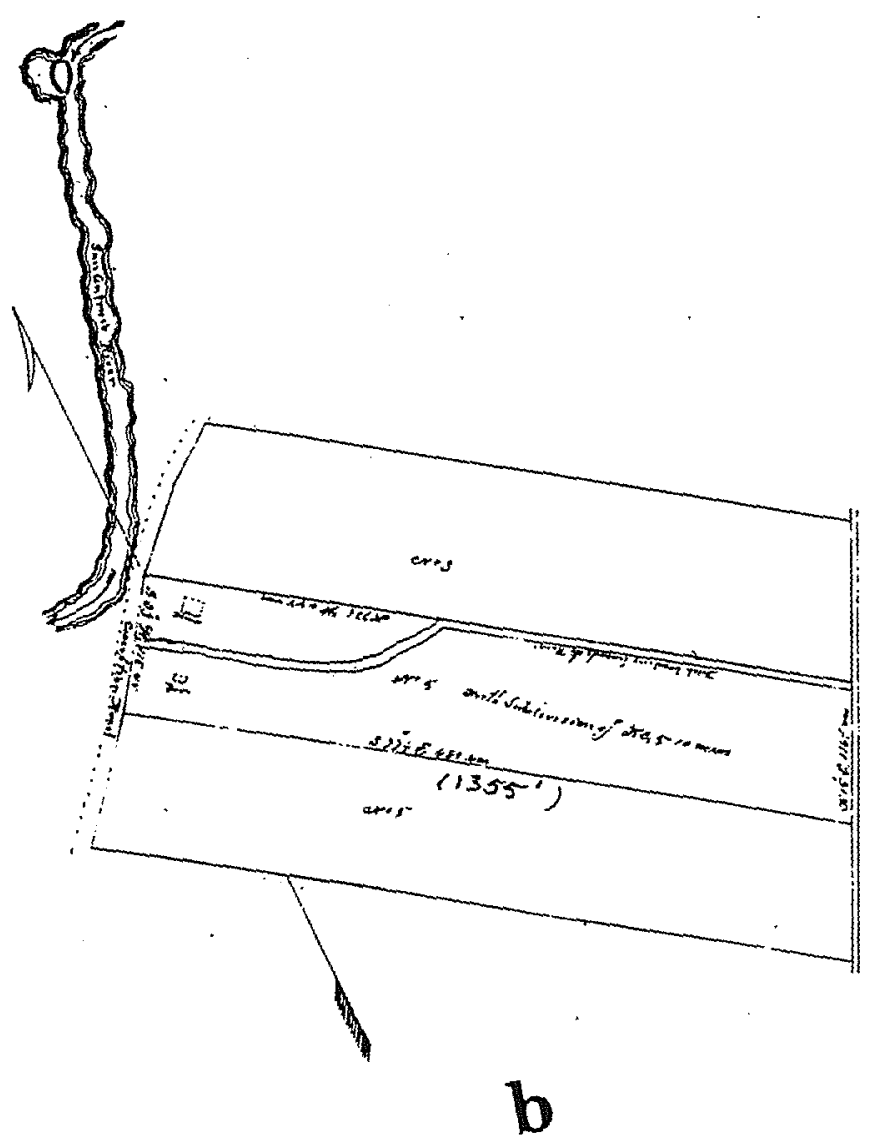

Figure 2. Survey plats of the Yturri-Edmunds properties. a, plat of $1863 ; \mathrm{b}$, plat of 1867 .

8 


\section{CONCLUSION AND RECOMMENDATIONS}

The project area is under consideration for development to function as a support area for the Yturri-Edmunds Historical Site. The existing board and batten structure (Unit F, formerly 514 Grove Avenue) appears to have been the residence of the Wenninger family during the development of the camp from 1925. This is based upon the similarity of the structure to one shown on a 1936 Sanborn Insurance map of the lot. Only the structures along the south property line are illustrated, but based upon that coverage, this is the only virtually intact structure of that period. Most of the tourist cabins have been either greatly altered or destroyed and replaced. The northern set of cabins would have almost surely been destroyed by development of the current parking lot situated to the north of the property under consideration. At the time of the Wenninger ownership, the area to the north to Grove Street would have been a part of the camp complex.
The old Concepción acequia, if it survives, lies to the western edge of the property and appears to be well below the present level of the property, most likely under fill as a result of one of several alterations to the course of the old Mission Road. Since no deep excavation is anticipated, it is doubtful that landscaping or improvement of the area will expose any evidence of an archaeological or historical nature. Therefore, no further work is recommended at this time. However, should demolition or construction reveal buried historical features, an archaeologist should be consulted immediately. 


\section{REFERENCES CITED}

Appler, J. A.

1895 General Directory of the City of San Antonio, 1895-1896. San Antonio.

1901 General Directory of the City of San Antonio, 1901-1902. San Antonio.

1903 General Directory of the City of San Antonio, 1903-1904. San Antonio.

1907 General Directory of the City of San Antonio, 1907. San Antonio.

1912 General Directory of the City of San Antonio, 1912. San Antonio.

Barnes, C. M.

1910 Combat and Conquest of Immortal Heros Sung in Song and Told in Story. Guessaz and Ferlet, San Antonio.

Belasco, W. J.

1979 Americans On The Road: From Auto Camp To Motel, 1910-1945. MIT Press, Cambridge, Massachusetts.

Branda, E. S.

1976 The Handbook of Texas, A Supplement, Volume III. Texas State Historical Association, Austin.

Chabot, F. C.

1937 With the Makers of San Antonio. Privately published, San Antonio.

Corner, W.

1890 San Antonio de Bexar: A Guide and History. Bainbridge and Corner, San Antonio.
Cruse, $\mathrm{K}$.

1985 History of the Yturri-Edmunds House and Mill, 257 Yellowstone, San Antonio, Texas. Unpublished manuscript on file at the San Antonio Conservation Society, San Antonio.

Donovan, $\mathrm{F}$.

1965 Wheels for a Nation. Thomas Y. Crowel, New York.

Fehrenbach, T. R.

1968 Lone Star, a History of Texas and the Texans. MacMillian, New York.

Habig, M. A.

1968 The Alamo Chain of Missions, a History of San Antonio's Five Old Missions. Franciscan Herald Press, Chicago.

Hill, F. E.

1967 The Automobile, How It Came, Grew and Has Changed Our Lives. Dodd, Mead, New York.

Keyton, C.

1960 Tourist Camp Pioneering Experiences. Adams Press, Chicago.

Morrison and Fourmy, publishers

1881 General Directory of the City of San Antonio, 1881-1882. Austin.

1885 General Directory of the City of San Antonio, 1885-1886. Galveston.

1887 General Directory of the City of San Antonio, 1887-1888. Galveston. 
Perry, R. B.

1948 On Early Tourist Courts in San Antonio. Unpublished manuscript, Vertical file "Hotels, Motels," San Antonio Public Library, Main Branch, San Antonio.

Polk, R. L.

1958 Polk's San Antonio City Directory, 1958. R. L. Polk and Company, Dallas.

1963 Polk's San Antonio City Directory, 1963. R. L. Polk and Company, Dallas.

1967 Polk's San Antonio City Directory, 1967. R. L. Polk and Company, Dallas.

1973 Polk's San Antonio City Directory, 1973. R. L. Polk and Company, Dallas.

1974 Polk's San Antonio City Directory, 1974. R. L. Polk and Company, Dallas.

1975 Polk's San Antonio City Directory, 1975. R. L. Polk and Company, Dallas.

1977 Polk's San Antonio City Directory, 1977. R. L. Polk and Company, Dallas.

1979 Polk's San Antonio City Directory, 1979. R. L. Polk and Company, Dallas.

1982 Polk's San Antonio City Directory, 1982. R. L. Polk and Company, Dallas.

Rodriguez, J. M.

1913 Rodriguez Memoirs of Early Texas. Standard Printing, San Antonio.
San Antonio Express (SAE) [San Antonio, Texas] 1926 "Over 20,000,000 Motor Vehicles." 3 January.

1953 Obituary notice, "Wenninger Death." 27 July.

Worley, J. F.

1924 San Antonio City Directory, 1924. San Antonio.

1926 San Antonio City Directory, 1926. San Antonio.

1929 San Antonio City Directory, 19291930. San Antonio.

1934 San Antonio City Directory, 19341935. San Antonio.

1936 San Antonio City Directory, 1936. San Antonio.

1939 Worley's San Antonio City Directory, 1939. John F. Worley Directory Company, Dallas.

1946 Worley's San Antonio City Directory, 1946. John F. Worley Directory Company, Dallas.

1948 Worley's San Antonio City Directory, 1948. John F. Worley Directory Company, Dallas.

1951 Worley's San Antonio City Directory, 1951. John F. Worley Directory Company, Dallas.

1957 Worley's San Antonio City Directory, 1957. John F. Worley Directory Company, Dallas.

Yass, $\mathrm{M}$.

1970 The Great Depression. Waylan Publishers, London. 
